\title{
CONSTRUCTION OF AGRICULTURAL RESEARCH IN THE CRIMEAN PENINSULA
}

\section{Viktor Vergunov}

\section{INTRODUCTION}

Numerous publications of a scientific and popular science character have proved that the Crimean peninsula is a unique component of the statehood of Ukraine in its various manifestations. To the full, it concerns the issues of farming on it. Historically, the Crimean agriculture has specialized in cereals, viticulture, horticulture, vegeculture, and the cultivation of essential oils (lavender, roses, and sage). Today, arable land (63.3\% of the total agricultural area) is predominant in the structure of agricultural lands, which occupy $63 \%$ of the territory of Crimea, followed by pastures 22.9 , perennial crops 8.7 and hayfields $0.1 \%$. Unique in its construction is the history of the organizational foundations of conducting industry research on the peninsula, both in terms of beginning and development during the tsarist era, and the system of changes during the RSFSR, when the Crimean region was part of until 1954.In February 19, 1954 Presidium of the Supreme Soviet of the USSR signed by its chairman Voroshilov K.E., given the community economy, territorial proximity, close economic and cultural ties between Crimea and Ukraine, the position of the RSFSR and the USSR governments, issued a decree "On the transfer of the Crimean region from the RSFSR to the USSR", and the law "On the transfer of the Crimean region from the RSFSR to the USSR" was passedon April 26, 1954. By the way, in 1954, instead of the Crimea, the Ukrainian SSR transferred to the RSFSR part of its original territories bordering the neighboring Russian regions, and gave the city Taganrog toRostov region. These lands cumulatively by area equated to the territory of the Crimea, inhabited by 1.2 million Ukrainians.

There is an urgent need to investigate the history of the origin, formation and development of agricultural research in the Autonomous Republic of Crimea, primarily as an organization, taking into account the specific climatic conditions of the region. This approach, according 
to the findings of the author's publication ${ }^{1}$, especially in the context of general conceptual approaches to the existence of sectoral research in Ukraine, has not yet been used. Other well-known publications are tangent or highly specialized. Amongst new editions it is necessary to name the Radchenko's V.A. booklet "Identity and difference of tendencies of development of domestic and foreign experience" 2 as a successful and logical continuation of the fundamental works of Zuev V${ }^{3}$., Klepinin M.M. ${ }^{4}$ and Kochkin M.A. ${ }^{5}$ It is appropriate to highlight one of the best comprehensive works on the formation and development of domestic agricultural research in the history of its study, prepared by Helina O.Yu. ${ }^{6}$ Among other things, it included the Imperial Nikitsky Botanical Garden, established in 1811, in the list of landmark institutions in the general concept of "garden science" as a precursor to experimental agronomy in the country. This conclusion is not accidental. In the early 80's of the XIX century the same vision was reasonably proved by Balthalona G.P. in his article inthe official bulletin of the Imperial Russian Societyof Horticulture - "Bulletin of horticulture, fruit growing and vegeculture".

1 Verhunov V.A. (2012) Selskokhoziaistvennoe opytnoe delo na Krymskom poluostrove: nauchno-orhanyzatsyonnyi aspekt (k 200-letyiu sozdanyia Nikitskogo botanycheskogo sada - Natsyonalnogo nauchnogo tsentra NAAN) [Agricultural experimental work on the Crimean peninsula: scientific and organizational aspect (on the 200th anniversary of the Nikitsky Botanical Garden - National Scientific Center of the NAAS)]: nauch. doklad. Kyev : FOP Korzun D. Yu. 32 p. (in Ukrainian).

2 Radchenko V. A. (2007) Ydentychnost y razvytye tendentsyi otechestvennoho y zarubezhnoho opыtnychestva [Identity and development of trends in domestic and foreign experience]. Symferopol: OAL Symferopolskaia gorodskaia typohrafyia (SHT). 100 p. (in Ukrainian).

3 Zuev V. (1787) Puteshestvennye zapysky Vasylia Zueva ot S. Peterburga do Khersona v 1781 y 1782 godu [Travel notes of Vasil Zuev from St. Petersburg to Kherson in 1781 and 1782]. Sankt-Peterburh. 273 p. (in Russian).

4 Klepynyn N. N. (1914) Krym, putevodytel [Crimea, guide]. Simferopol. pp. 28-49. (in Ukrainian).

5 Kochkyn M. A. (1967) Pochvy, lesa i klymat gornoho Kryma i puti ikh ratsionalnogo ispolzovanyia. Nauchnye trudy [Soils, forests and climate of the Crimea mountainous and ways of their rational use. Scientific works]. Moskva: Kolos. T. XVIII. 368 p. (in Russian).

6 Elyna O. Yu. (2008) Ott sarskykh sadov do sovetskykh polei: istoryia selskokhoziaistvennykh opytnykh uchrezhdenyi XVIII - 20-e gody XX v. [From Tsarist Gardens to Soviet Fields: the History of Agricultural Experimental Institutions of the XVIII - 20th years]: v 2 t. Moskva. T. 1. 480 p., T. 2. 488 p. (in Russian). 
Moreover, he claimed that "Crimea is a copy of the Caucasus. These two quadrilaterals are so different in administrative terms, in geographical terms they have a lot in common: from the west and east, both are surrounded by the seas, and the Caspian Sea corresponds to the Azov: the regions have a steppe character, but equally to the south of it nature shines with the luxury and wealth of its gifts". While highlighting the scientific significance of the Imperial Nikitsky Botanical Garden, and especially its practical role for domestic agriculture and, above all, on the peninsula, the scientist insisted that "...almost all exotic shrubs and trees grown on the southern coast of Crimea came from this garden. ... many of these plants are for sale ... hundreds and thousands of specimens, such as, for example, palm trees, boxwoods, cypresses, laurels, evergreen oaks and more",

\section{Features of the development of the agricultural sector in the Crimea}

Our own historical research into the scientific and organizational forms of agricultural science proves that the first research institution of agrarian profile in the modern vision of this concept for Ukraine is the present Nikitsky Botanical Garden - National Scientific Center of the National Academy of Agrarian Sciences of Ukraine and that in many respectsoriginate of state interest to research in agriculture is related to humiliating defeat of the Russian army in the Crimean War of $1853-1856^{8}$, as well as the influence of all the progressive of the leading agrarian countries of Europe, especially France and some French .

${ }^{7}$ Baltalona H. P. (1882) Imperatorskyi Nikitskyi sad v Krymu [Imperial Nikitsky Garden in Crimea]. Vestnyk sadovodstva, plodovodstva $i$ ogorodnichestva (orhanmImperatorskoho Rossyiskoho obshchestva sadovodstva). Oktiabr. pp. 528-537; noiabr. pp. 567-573; dekabr. pp. 628-634. (in Russian).

${ }^{8}$ Verhunov V. A. (2000) Vynyknennia doslidnoi spravy v zemlerobstvi Ukrainy: pivdenno-skhidnyi aspekt [The origin of a research case in Ukrainian agriculture: the southeastern aspect]. Aktualni problem istorii ahrarnoi nauky pivdnia Ukrainy (Ukraine. Kyiv. Cherven', 12, 2000). Kyiv. pp. 6-7. (in Ukrainian).

${ }^{9}$ Verhunov V. A. (2009) Ahronomiia i stanovlennia nauky pro tvarynnytstvo na terenakh Ukrainy ta Frantsii (druha polovyna XVIII st. - 1920 rik) [Agronomy and the formation of animal science in the territory of Ukraine and France (second half of the eighteenth century - 1920)]. Kyiv. 280 p. (in Ukrainian). 
What was the agriculture of the region after the fifteen years of peaceful annexation of Crimea to Russia in accordance with the "Supreme Command" of Empress Catherine II of April 8, 1783 or in the process of originating the idea of finding ways to improve its productivity at the expense of scientific knowledge, it is possible to make an impression from the Sumarokov's P.I. book “A journey across Crimea and Bessarabia in 1799 with a historical and topographical description of all those places". The future academician of the Russian Academy of Sciences, the secretary adviser and the member of the Crimean commission (1801-1802) in the fashionable for that time genre of "sentimental journey", in telling, he calls Tavrida a "treasure chest".

Considering the natural and climatic conditions of Crimea, as well as the historical features of development on the way to the constituent of present Ukraine, there arethe interest and analysis of the formation of agricultural research to the events of 1917, which, of course, has many definitively unexplored moments, for example, in the general context of evolution of scientific-organizational structure of the national branch of science, its specialization, as well as the personalized contribution of individuals, in particular the French.

Considering at this angle the task, it should be noted that historically the Crimean peninsula was determined to deal with agriculture and increase the productivity of its components. As time passed, there were no other ways for this distinctive region of Ukraine. That was completely comprehensible to the state men of the tsarist era, who had the honor to deal with the problems of the development of the Crimea, beginning with Knyazh Potemkin G.O. at the end of the XVIII century, Count Vorontsov S.M. and especially the Duke de Richelieu. The latter, apparently, is associated with the origin of sectoral research on the peninsula in its modern sense, when a permanent operating institution used a special method of conducting field or laboratory research, and there was a state interest in their conduct, which is all responsible for Elina's O.Yu. socio-cultural concept of "patronage" that was systematically prepared in 2007 and dedicated to the

${ }^{10}$ Elyna O. Yu. (1995) Nauka dlia selskogo khoziaistva v Rossyiskoi imperii: formy patronazha [Science for agriculture in the Russian Empire: forms of patronage]. Sotsialnaya istoryia otechestvennoi nauki i tekhniki, no 1, pp. 40-63. (in Russian). 
$200^{\text {th }}$ anniversary of the Nikitsky Botanical Garden - National Scientific Center of NAAS ${ }^{11}$, as well as a special historical dissertation research by Potechin V.E. ${ }^{12}$ The well-illustrated Kryuk'sI. monograph "Nikitsky Botanical Garden. History and fate" should also be mentioned, which was alsodedicated to the 200th anniversary and released in $2011^{13}$. The whole process in the evolutionary context was considered by academician Adamen F.F. ${ }^{14}$

Obviously, the origin of agricultural research in agronomy,this is exactly how they talked about agriculture in the second half of the eighteenth century, was largely linked to the common European vision of its physiocratic development. Having the French roots of concept, its best theorists considered the land and agriculture is the onlya source of wealth, and "agriculture is the only productive labor"15. Otherwise it could not be for tsarist Russia, which remained an exclusively agrarian country with $90 \%$ rural populationin the early XIX century.

Continuing to find ways to maximize the benefits of agricultural production through, first of all, its realization on foreign markets after a "successful" experiment - entering the Baltic Sea, Russia had high hopes on adjacent land to the Black and Azov Seas. It is no accident in 1868 that one of the best connoisseurs of agriculture in the south of Russia and the level of his scientific support, Professor Palimpsestov I.V. (1818-1901) wrote: "In Russia... the value of the products of the earth...

11 Mytrofanov V. Y. (2007) [y dr.]. Mechta gertsoga de Ryshele - Nikitskyi botanycheskyi sad [Dream of the Duke de Richelieu - Nikitsky Botanical Garden]. Yalta: Dana Publishing, Poly PRESS. 56 p. (in Ukrainian).

12 Potekhyn V.E. (1976) Nikitskyi botanicheskyi sad v razvitii selskogo khoziaistvayuga Rossii (1812-1861 gg.) [Nikitsky Botanical Garden in the Development of Agriculture in the South of Russia (1812-1861)]: avtoref. dys. na soyskanye nauch. step. kand. yst. nauk. Moskva. 32 p. (in Russian).

${ }^{13}$ Kriukova Y. (2011) Nikitskyi botanycheskyi sad. Istoryia i sud'by (k 200-letnemu yubyleiu) [Nikitsky Botanical Garden. History and fate (on the occasion of the 200th anniversary)]. Simferopol: N. Oryanda. 415 p. (in Ukrainian).

14 Adamen F.F. (2011) Vnedrenye agronomycheskykh nauchnykh razrabotok v agropromyshlennom komplekse Ukrayny [Introduction of agronomic scientific developments in the agricultural sector of Ukraine]. Kyiv: Ahrar. nauka. 60 c. (in Ukrainian).

Potekhyn V.E. (1976) Nikitskyi botanicheskyi sad v razvitii selskogo khoziaistvayuga Rossii (1812-1861 gg.) [Nikitsky Botanical Garden in the Development of Agriculture in the South of Russia (1812-1861)]: avtoref. dys. na soyskanye nauch. step. kand. yst. nauk. Moskva. P. 5. (in Russian). 
is the value of everything received from trade, factories and factoriesin ten times. Therefore, agriculture is not only a major a source of prosperity and wealth for it, but it is also the only, and far that time, when other industries will occupy a more prominent place in this country - and still will"16. Speaking about the Crimea and the entire Southwestern region as of the middle of the 19th century, after the annihilation of serfdom in the country and active "education" of its population, this researcher, who gave more than fifty years to study the region, insisted: "...dare I say that Russia did not understand the importance of this region and therefore did not do what it should do for it" $"$.

We only need to agree with him on this vision of the issue, as well as with the fact that there is no talk of systematic research for the needs of the region's agriculture at that time. Although Palimpsestov I.V. also cites the results of individual experiments in animal husbandry, winemaking and crop production by the large landowners of the region at that time. Yes, he notes that sheep breeding makes a big profit: "We send abroad wool over 500 thousand poods"18. Assessing the state of horticulture, he insists that "...we do not have horticulture"19. He provides data on the effectiveness of winemaking of the region, namely the receipt of products "...more than 4 million species" by the provinces of the Southwestern Territory (Tavriysk, Kherson, Bessarabia and Katerinoslavsk)in 1851.He indicates a decrease in productivity in mulching from 300 poods in $1833-1835$ to 180 poods in 1849 and cites

16 Palympsestov Y. (1868) Obozrenie razlichnykh otraslei selskogo khoziaistva [Overview of various agricultural sectors]. Sbornik statei o selskom khoziaistve Yuga Rossiii zvlechennykhiz. Zapisok Imperatorskogo obshchestva selskogo khoziaistvayuzhnoi Rossii s 1830 po 1868 god. Odessa: Typ. P. Frantsova. P. 49. (in Russian).

17 Palympsestov Y. (1868) Obozrenie razlichnykh otraslei selskogo khoziaistva [Overview of various agricultural sectors]. Sbornik statei o selskom khoziaistve Yuga Rossiii zvlechennykhiz Zapisok Imperatorskogo obshchestva selskogo khoziaistvayuzhnoi Rossii s 1830 po 1868 god. Odessa: Typ. P. Frantsova. P. 50. (in Russian).

18 Palympsestov Y. (1868) Obozrenie razlichnykh otraslei selskogo khoziaistva [Overview of various agricultural sectors]. Sbornik statei o selskom khoziaistve Yuga Rossiii zvlechennykhiz Zapisok Imperatorskogo obshchestva selskogo khoziaistvayuzhnoi Rossii s 1830 po 1868 god. Odessa: Typ. P. Frantsova. P. 54. (in Russian).

19 Palympsestov Y. (1868) Obozrenie razlichnykh otraslei selskogo khoziaistva [Overview of various agricultural sectors]. Sbornik statei o selskom khoziaistve Yuga Rossiii zvlechennykhiz Zapisok Imperatorskogo obshchestva selskogo khoziaistvayuzhnoi Rossii s 1830 po 1868 god. Odessa: Typ. P. Frantsova. P. 56. (in Russian). 
the reason "...lack of land ownership for the peasantry" 20 . Among the new crops, thanks to the Frenchman Vasselen Reno, who rented Knyazh Kochubey'sland in the Crimea, showed a high efficiency of madder (Rubiatinctórum) with a yield of 400 poods and a profit of 50 tenths equal to 50,000 rubles in the space of 2 years. By the way, Steven H.H. owns the first methodological guide for growing this culture in Crimea. The second culture, no less effective for the region, according to Palimpsestov I.V., according to the data of Nikitsky Botanical Garden, was common teasel with an annual net profit of 300 rubles in silver. This leading representative of the Imperial Agricultural Society of the South of Russia, which actually synthesized everything new and progressive in the industry, and especially regarding its introduction since 1830, gaveaway the future in arable farming of Crimea to such cultures as "...hops, coloring buckwheat, which gives very valuable blue paint, indigo woad, saffron, safflower, rapeseed, sunflower..."21 in addition to traditional field crops.

Important place in the agrarian future of the region, he gave away castor and tobacco. Concerning animal husbandry Palimpsestov wrote: "The main families of our domestic animals - horses and cattle, in the total mass, that is, they are in the hands of the people, compared with the horses and cattle of England, Belgium, Holland, Germany and France,rather, they can be called parodies of these animals than real animals under the care of intelligent beings, that is, human beings" ${ }^{, 22}$. This is all about research in this area at that time.

To sum up, he calls among the reasons holding back the development of the country's productive forces, “...land ownership and

${ }^{20}$ Palympsestov Y. (1868) Obozrenie razlichnykh otraslei selskogo khoziaistva [Overview of various agricultural sectors]. Sbornik statei o selskom khoziaistve Yuga Rossiii zvlechennykhiz Zapisok Imperatorskogo obshchestva selskogo khoziaistvayuzhnoi Rossii s 1830 po 1868 god. Odessa: Typ. P. Frantsova. P. 57. (in Russian).

${ }^{21}$ Palympsestov Y. (1868) Obozrenie razlichnykh otraslei selskogo khoziaistva [Overview of various agricultural sectors]. Sbornik statei o selskom khoziaistve Yuga Rossiii zvlechennykhiz Zapisok Imperatorskogo obshchestva selskogo khoziaistvayuzhnoi Rossii s 1830 po 1868 god. Odessa: Typ. P. Frantsova. P. 58. (in Russian).

${ }^{22}$ Palympsestov Y. (1868) Obozrenie razlichnykh otraslei selskogo khoziaistva [Overview of various agricultural sectors]. Sbornik statei o selskom khoziaistve Yuga Rossiii zvlechennykhiz Zapisok Imperatorskogo obshchestva selskogo khoziaistvayuzhnoi Rossii s 1830 po 1868 god. Odessa: Typ. P. Frantsova. P. 61. (in Russian). 
use rights, millions under the gun ..., the lack of modern means of communication..." There are reasons to argue that many of the above are relevant in 150 years.

The above detailed analysis of the agriculture of the southern regions of the country, and especially of the Crimea, quite objectively reflects the picture of its condition and does not mention the systematic and, especially with the state interest, research for their solution. Demonstration results, especially in field farming, are fragmentary. In the first half of the XIX century, in fact, only the Nikitsky Botanical Garden is active for the needs of the region, mainly in the areas developed by its first director Steven H.H.: “...receiving the proper seeds and seedlings for the country at a reasonable price. And the goals set for the near future, in a concise formulation, looked like this: acclimatization and practical assistance in creating gardens" ${ }^{\prime 23}$. All these directions are successfully represented by this scientific institution till this day with the addition of studying the issues of processing of the obtained products. In this case, the Nikitsky Botanical Garden is not only leading and recognized on the peninsula, but also in the country and in the world.

\section{Formation of agricultural research}

The appearance of the Nikitsky Botanical Garden is largely related to the names of the German, academician of the Imperial Petersburg Academy of Sciences Pallas Petr Simon and Frenchman - Arman Emmanuel du Plessis Duke de Richelieu. Although we associate the name of German with stateinterest to the development of winemaking and the opening in the Crimea in 1802 of the first agricultural institution - the school of winemaking in the Sudak valley in the Achillarregion. It is this famous naturalist, traveler and first researcher of the Crimea, professor of natural history since 1767, became its first director. The establishment of the school was the starting point when the development of winemaking in the region received real state support, because at that time, “...origin ... in the land of gardening was

${ }^{23}$ Sekurov N. K. (1998) Tri vstrechi s Khrystyanom Stivenom [Three meetings with Christian Steven]. Symferopol. P. 14. (in Ukrainian). 
given to their own forces"24. In Elina's O.Yu. idea, a collection of grape vines from the estate of academician Pallas P.S.in Sudak, which before his departure to Germany he presented to the outstanding Russian agronomist Afonin M.I., as well as vines from his own collection of research nurseries, "...formed the basis for the collections of the Tavriisky (Nikitsky) Botanical Gardens". 25

Another fundamental step was made by the Kherson military governor Duke de Richelieu, who published in 1811 a report on the basis of which Emperor Alexander Pavlovich instructed him to arrange a garden "... both to improve the species of local fruit trees and plant breeding of foreign plants, corresponding to the favorable climate of the southern coast of Crimea".

In a letter addressed to the Minister of Internal Affairs of December 11, 1811, he also chose a place for the future garden Smirnova's cottage - an area of 374 acres, as well as its first director a famous botanist originally from Sweden, a graduate of the Military Medical Academy, an assistant chief inspector on mulching collegiate advisor Steven H.H. On February 22, 1815, Christian Khristianovich was elected Corresponding Member, and on October 6, 1849, he was elected an honorary member of the Imperial Academy of Sciences of Russia $^{26}$.

Duke de Richelieu also approved the first plan of scientific and organizational work of the "economic-botanical" garden, submitted January 9, 1813 in the form of Steven's H.H. Report. The governor donated 1000 rubles for the arrangement of the garden and sent 10 tea bushes from Paris ${ }^{27}$. Earl Langeron, a Frenchman by origin, who

${ }^{24}$ Shcherbakov M. F. (1911) Imperatorskyi Nikitskyi sad. 1910 [Imperial Nikitsky Garden. 1910]. Ezhehodnyk Hlavnoho Upravlenyia Zemleustroistva y Zemledelyia po Departamentu zemledelyia (hod chetvertbi). Peterburg, p. 631. (in Russian).

25 Elyna O. Yu. (2008) Ott sarskykh sadov do sovetskykh polei: istoryia selskokhoziaistvennykh opytnykh uchrezhdenyi XVIII - 20-e gody XX v. [From Tsarist Gardens to Soviet Fields: the History of Agricultural Experimental Institutions of the XVIII - 20th years]: v 2 t. Moskva. T. 1. P. 161. (in Russian).

26 Nauka. (1974) Stiven Khrystyan Khrystyanovych [Steven Christian Hristianovich]. Akademyia nauk SSSR. Personalnyi sostav. Kn. 1 (1724-1917). Moskva. P. 107. (in Russian).

${ }^{27}$ Shcherbakov M. F. (1911) Imperatorskyi Nikitskyi sad. 1910 [Imperial Nikitsky Garden. 1910]. Ezhehodnyk Hlavnoho Upravlenyia Zemleustroistva y Zemledelyia po Departamentu zemledelyia (hod chetvertbii). Peterburg, p. 635. (in Russian). 
replaced Duke de Richelieu as Governor-General of Novorossiysk, also strongly supported Steven H.H. Richelieu remembered one of his best and nobler "pet project" after leaving Russia. Through his mediation, the French Minister of the Interior, Duke Dekaz, promoted the acquisition of vines for the Magarach Winery in 1815 - "...the first nursery of winemaking knowledge in Russia" 28 from a Luxembourg nursery near Paris. Richelieu sends acorns of cork tree for garden from Parisin 1817. Thus, he maximally contributed to the development of research in the Nikitsky Botanical Garden ${ }^{29}$.

It should be noted that at the initial stage of the formation of the Nikitsky Botanical garden majority of fruit trees were imported from France for the first regular pomological garden, which was laid in 1817.Despite the positive moments, there were also negative ones. As the authors of the beautiful modern edition of "The Duke de Richelieu's Dream - Nikitsky Botanical Garden” write: “...along with the cultural plants accidentally brought weeds in the Crimea - a herbaceous ditch-bur with earth on the roots of trees from Paris in 1815, and the tree of the ailanthus, which easily became wild and a vicious weed..."30. However, every year the garden has expanded its activities in the best European traditions. Visiting it in 1818, Emperor Alexander I was amazed to see and awarded de Richelieu, who had already left the country, the highest award of the empire - The Order of St. Andrew the First-Called for the transformation of the Novorossiysk land and garden, as well as southern Crimea, which the great son of the French people considered "more beautiful than the French Riviera".

Interestingly, the final decision to organize the water supply of the Nikitsky Botanical Garden, which actually exists to this day, goes under the name of the Minister of Agriculture and State Property of the Russian Empire, Ermolov O.S. and French scientist, specialist in

${ }^{28}$ Shcherbakov M. F. (1911) Imperatorskyi Nikitskyi sad. 1910 [Imperial Nikitsky Garden. 1910]. Ezhehodnyk Hlavnoho Upravlenyia Zemleustroistva y Zemledelyia po Departamentu zemledelyia (hod chetvertbii). Peterburg, pp. 630-645. (in Russian).

${ }^{29}$ Shcherbakov M. F. (1911) Imperatorskyi Nikitskyi sad. 1910 [Imperial Nikitsky Garden. 1910]. Ezhehodnyk Hlavnoho Upravlenyia Zemleustroistva y Zemledelyia po Departamentu zemledelyia (hod chetvertbii). Peterburg, p. 637. (in Russian).

${ }^{30}$ Mytrofanov V. Y. (2007) [y dr.]. Mechta gertsoga de Ryshele - Nikitskyi botanycheskyi sad [Dream of the Duke de Richelieu - Nikitsky Botanical Garden]. Yalta: Dana Publishing, Poly PRESS. p. 26. (in Ukrainian). 
hydrology and speleology Martel. In the summer of 1903, State Secretary Yermolov A.S. made a trip to Crimea. Along with other objects, he inspected the Salgirgovernment-owned Garden near Simferopol, as well as the Imperial Nikitsky Botanical Garden, which the minister had previously visited on August 30, 1893, in connection with the project of reorganizing the gardening school, which was part of the garden ${ }^{31}$. His current arrival was due to urgent problems with the water supply of the garden.

To this end, Yermolov A.S. took along a well-known specialist in Europe, Martel, who, first of all, was formally invited "...to hydrologically investigate the Black Sea coast of the Caucasus". In advance, before the official visit of the Minister, Martel became acquainted with the problems of Nikitsky Botanical Garden'swater supply. During the discussion, the French specialist offered constructive suggestions, which, in general, Yermolov A.S. approved for action ${ }^{32}$. A little later, under the impression of what he saw, in his report at the 2nd All-Russian Congress of Experimental Affairs, Yermolov A.S. not only put the Imperial Nikitsky Botanical Garden first among those institutions that should be engaged in "...the broad production of experiments and the acclimatization of plants in our country, interesting scientifically or effective from a practical point of view..." but also proposed to take charge of developing a general program of this type of research in the empire ${ }^{33}$.

The results of a basic study that looks at the evolutionary path traveled on the Crimean peninsula from the gardens and parks of the Southern coast of Crimea to the existence in the region of agricultural

${ }^{31}$ Petrov Y. P., Vereshchahyn N. V. (ed.) (1893) O puteshestvii po Rossii Ministra Zemledelyia [About the trip to Russia of the Minister of Agriculture]. Vestnik russkogo selskogo khoziaistva, no 36 (4 sentiabria), p. 609. (in Russian).

32 Typohraf. V. F. Kyrshbauma. (1904) Obzor deiatelnosti Ministerstva zemledelyia i gosudarstvennykh imushchestv za desiatyi god ego sushchestvovanyia [Overview of the activities of the Ministry of Agriculture and State Property for the tenth year of its existence]. Sankt-Peterburh. P. XII. (in Russian).

${ }^{33}$ Kudashev V. A. (ed.) (1903) O neobkhodymosty luchshei orhanizatsyy opytnykh kultur, a ravno opytov po akklymatyzatsi i novykh i maloyzvestnykh rastenyi $\mathrm{v}$ razlychnykh mestnostiakh Rossii. Doklad 2-mu siezdu A. S. Ermolova [On the need for better organization of experimental crops, as well as experiments on the acclimatization of new and little-known plants in various places of Russia. Report of A. S. Ermolov to the 2nd Congress]. Zemledelcheskaia hazeta, no 5, p. 155. (in Russian). 
research as an organization, are summarized in a series of publications by Stashkina (Adamen)A.F. She identified its main styles and trends: monastic, Dutch, forest, august, dangling, "paradise" garden, world nature, which are generally attributed to the European. No less noticeable was the Asian influence of Chinese, Japanese and Moorish styles. Their successful application was facilitated by Englishmen and Frenchmen who taught Russian students.

After all, industry research has developed as a component of national culture ${ }^{34}$. The rest of all components of agriculture of the Crimean peninsula has developed due to the evolution of sectoral scientific and educational thought in the country. In our view, this is a principled approach to what we are investing today in the concept of "agricultural research". It is not necessary to downplay the value, according to Elina O.Yu., the initiative of "patrons" from personal landowners to various types of state monopoly. But if there were no real victories or discoveries of domestic agricultural science, there would be no desire to invest money in this business.

Let's consider the scientific and organizational structure of the network of agricultural research institutions of the Crimea as of 1913 inclusive - the period of the highest prosperity of the Russian Empire on agriculture, referring to the official statistical reporting of the Department of Agriculture ${ }^{35}$. Interestingly, the Nikitsky Botanical Garden is not mentioned in it as the subject of a functioning network of agricultural institutions in the country. According to the "Data Collection", in 1910 there were 130 research institutions reporting on their activities, and in 1913 there were 195in the country. Structurally, they were divided into groups: 1) laboratories, 2) research stations, 3) research fields, 4) research farms, 5) nurseries. This did not include research parcels of educational branch institutions. Of the 256 educational institutions, only 54 were currently engaged in

${ }^{34}$ Adamen A. F. (2009) Evoliutsyia landshaftov v Krymu (s peryoda antychnostypo nastoiashchee vremia) [The evolution of landscapes in the Crimea (from the period of antiquity to the present)]. Ahroekolohichnyi zhurnal, Cherv (spets. vyp.), pp. 27-31. (in Ukrainian).

${ }^{35}$ Typo-lytohr. M. P. Frolovoi. (1911) Sbornyk svedenyi o selskokhoziaistvennыkh орыtnыkh uchrezhdenyiakh Rossyy (po dannыm anketы 1910 hoda) [Collection of information on agricultural experimental institutions of Russia (according to the data of 1910).]. Sankt-Peterburg. 394 p. (in Russian). 
research.According theofficial reporting on this category, Tavriyan province was officially represented by the Nikitsky School of Horticulture and Viticulture with an experimental site of 1 tenth.

It is clear that these experiments were rather demonstrative. The calculations showed that the empire's research network, available for analysis, was served by 215 workers with tertiary and secondary education and 265 without education (technical staff) ${ }^{36}$. In addition, 42 faculty members and civil servants were involved in this work. The cost per scientist at that time averaged 1411 rubles. The total budget of the existing network of the country was 627780 rubles $^{37}$.

According to official reports, as of 1913, the research network of sectoral establishments of the Tavriya province consisted of only four institutions, namely: the Simferopol Research Field, the Oleshkovsky state-owned Grapes Nursery, the Oleshkovka Tobacco Plot and the Yalta Tobacco Plantation ${ }^{38}$. However, under the current territorial division of Ukraine, both Oleshkiv stations are no longer owned by the Crimea. However, their main function of scientific support they certainly performed for the peninsula. Thus, the Oleshkovsky stateowned Grape Nursery (aka disinfectant) was founded by the Odessa Philocserny Committee and was located in two miles from Oleshka. The nursery was established in 1897 with public funds. Until January 1, 1908 he was governed by Bertenson V.A. and then Tairov V.E. The area of experiments is 34 arpent (tenths) of quicksand. First,it was laid to breed American and then European vines and a vineyard. Less known is the activity of the Simferopol Research Field, created in 1908 by the Simferopol County Zemstvo, located in 20 miles away

${ }^{36}$ Typo-lytohr. M. P. Frolovoi. (1913) Sbornyk svedenyi o selskokhoziaistvennykh opytnykh uchrezhdenyiakh Rossyy (po dannym ankety 1912 hoda) [Collection of information on agricultural experimental institutions of Russia (according to the data of the 1912)]. Sankt-Peterburg. Vol. 2. P. 67. (in Russian).

37 Typo-lytohr. M. P. Frolovoi. (1913) Sbornyk svedenyi o selskokhoziaistvennykh opytnykh uchrezhdenyiakh Rossyy (po dannym ankety 1912 hoda) [Collection of information on agricultural experimental institutions of Russia (according to the data of the 1912)]. Sankt-Peterburg. Vol. 2. P. 87. (in Russian).

38 Typo-lytohr. M. P. Frolovoi. (1913) Sbornyk svedenyi o selskokhoziaistvennykh opytnykh uchrezhdenyiakh Rossyy (po dannym ankety 1912 hoda) [Collection of information on agricultural experimental institutions of Russia (according to the data of the 1912)]. Sankt-Peterburg. Vol. 2. P. 67. (in Russian). 
from the city. Schneider F.F. provided his land for research for 10 years. The area of the experiments was 10 tenths.

The Yalta Experimental Tobacco Plantation was organized in 1911 by the Yalta County Zemstvo within the city. Experimental area of 0.5 tenthswas rented.

The research program as a component for all Crimean research institutions that studied theproblem of tobacco was developed by Euko V.E. It was approved by a special meeting in Simferopolin 1910.The general program was formed by Egiza S.A., Dahl K.V., Yevko V.E. and Khodasevich B.C. The first report of the plantation was sent to the Department of Agriculturein 1911.Therewas found the information about another research institution - Feodosia Research Mountain Mining and Cultural Forestry, classified by the Department of Agriculture as agricultural. It was created in 1902 by the Forest Department at a distance of 111 miles from Simferopol on full state content of 7,000 rubles. The area of the experimental site was 180 tenths. To the listed network of sectoral research institutions that operated in the Tavrian province before the revolutionary events of 1917, one more should be added. For various reasons, its activities are also almost forgotten and require additional historical exploration. In 1888, the Bartoshevich'sproperty in the Otuz Valley of the Feodosia County of Tavriya Province was purchased by the Ministry of State Property for the construction of an exemplary production holding of about 23 acres. Certain organizational problems related to world market prices did not allow the project to unfold immediately ${ }^{39}$.

Oddly enough, it is also worth mentioning that the Izmail nursery of the American Vines, created by the Department of Agriculture in 1897 in two versts from the city of Izmail, was connected withthe Nikitsky Botanical Garden, first of all, through scientific and methodological consultations and activities. In 1906 it was transferred to the Izmail Zemstvo and served the similarly-named district. It had 8 nurseries of American vines.Initially, it occupied 5 acres of land, and in 1908 - already 20 acres.

${ }^{39}$ Romanovskyi-Romanko A. S. (1910) Vynohradnyky y maslychnыe pytomnyky Departamenta zemledelyia [Vineyards and oil nurseries of the Department of Agriculture. 1909 1909]. Ezhehodnyk Hlavnoho upravlenyia zemleustroistva y zemledelyia po Departamentu zemledelyia (hod tretyi). Sankt-Peterburg : Typ. V. F. Kyrshbauma. P. 142. (in Russian). 
In 1909 a building for the manager, a workshop for vaccinations, a greenhouse and a cellar was built. The fight against phylloxera and the promotion of viticulturewasthe main area of scientific interest.On average, 100,000 thin cuttings for grafting and 50,000 thick cuttings were planted annually. The first sold at a price of 3 rubles for one thousand pieces, the other -5 rubles $^{40}$. In fact, in the state reports, this is all information about the work of Crimean research institutions until 1913. However, in 1917, according to Elina's O.Yu. data, there were $370^{41}$ research establishments in Russia, and according to other sources $-378^{42}$, which, of course, also increased in number over the next four yearsin the Tavria province. It was found that a special inspector, who was located in the city of Simferopol, was engaged in the general issues of agriculture in Tavria province. Dahl K.V. was appointed to this position in 1910.ShleiferV.A. provided agronomic assistance to the population and Shchuko S.S. worked at the position of the provincial agronomist-land manager. It should be noted that agrarian scientists who worked in the Crimea, repeatedly until 1917, raised the issue of the creation of a special Central Agricultural Research Station in order to summarize the introduction of everything new by coordinating efforts. In this regard, it is of interest "Project of organization of research institutions", which was prepared by Klepinin M.M. ${ }^{43}$ and submitted by the Provincial Agricultural Councilon December 6, 1912.

${ }^{40}$ Romanovskyi-Romanko A. S. (1910) Vynohradnyky y maslychnыe pytomnyky Departamenta zemledelyia [Vineyards and oil nurseries of the Department of Agriculture. 1909 1909]. Ezhehodnyk Hlavnoho upravlenyia zemleustroistva y zemledelyia po Departamentu zemledelyia (hod tretyi). Sankt-Peterburg : Typ. V. F. Kyrshbauma. P. 139. (in Russian).

41 Elyna O. Yu. (2008) Ott sarskykh sadov do sovetskykh polei: istoryia selskokhoziaistvennykh opytnykh uchrezhdenyi XVIII - 20-e gody XX v. [From Tsarist Gardens to Soviet Fields: the History of Agricultural Experimental Institutions of the XVIII - 20th years]: v 2 t. Moskva. T. 1, P. 120. (in Russian).

42 Elyna O. Yu. (1995) Nauka dlia selskogo khoziaistva v Rossyiskoi imperii: formy patronazha [Science for agriculture in the Russian Empire: forms of patronage]. Sotsialnaya istoryia otechestvennoi nauki i tekhniki, no 1, p. 61. (in Russian).

${ }^{43}$ Klepynyn N. N. (1913) Proekto rhanyzatsyy opytnykhuch rezhdenyi v Tavryiskoi gubernii: (doklad Gubernskomu Selskokho ziaistvennomu Sovetu 6 dekabria 1912 goda) [The project of the organization of experimental institutions in the Tavrian 
The project partly confirms our conclusion that there is an interest in the development of research in agriculture in different sections of society as "... a consequence of the general development of agronomic assistance to the population". According to Klepinin M.M., the issue of the organization of agricultural research institutions in Tavriya province was the subject of active discussion at various meetingsand sessions in 1911-1912.

Today, practically all well-known researchers of domestic research, for the needs of agriculture, call the Wiener's V.V.project on the division of the country into agricultural areas asone of the fundamental moments of its further development in general and organizational approaches in particular, which was based on botanical and geographical principles ${ }^{44}$. Thus, in 1908 the country was divided into 6 crop regions with 27 districts. According to Viner V.V. Tavriyaprovince became the part of the steppe region with chernozem and chestnut soils.But this successfully implemented plan was preceded by another project, widely discussed by experts and published in 1898 by a special brochure "The Project Organization of Research Fields in Russia"45, designed by Rothmistrov V.R.

The final impetus for the implementation of the system of regional organization of domestic research in the empire was the statement of 34 members of the State Duma "...to take decisive measures ... to identify the best ways of managing in certain parts of Russia, which differ in terms of climate, soil and economic environment..." and "...to immediately set up, on the correct grounds, a network of properly equipped agricultural research institutions...”.

Such a small legal and organizational excursion to the principled approaches to the organization of research institutions in the Tavriya province is no accident.

province: (report to the Provincial Agricultural Council on December 6, 1912)]. Simferopol: Typ. Tavryisk. Hub. Zem-va. 20 p. (in Ukrainian).

44 Elyna O. Yu. (2008) Ott sarskykh sadov do sovetskykh polei: istoryia selskokhoziaistvennykh opytnykh uchrezhdenyi XVIII - 20-e gody XX v. [From Tsarist Gardens to Soviet Fields: the History of Agricultural Experimental Institutions of the XVIII - 20th years]: v 2 t. Moskva. T. 1. 480 p., T. 2. 488 p. (in Russian).

45 Rotmystrov V. H. (1898) Proekt orhanizatsii opytnykh polei v Rossii [The project for the organization of experimental fields in Russia]. Odessa: Ekonomycheskaia typohraf. ilytohraf. 108 p. (in Ukrainian). 
Klepinin M.M. proposed his plan as a form of implementation of the Viner'svision, but rather- as its optimization on soil features. According to Viner V.V. the Odessa regional station's activity would be spread to the Crimean Peninsula, which explored chestnut soils. The other part of the Tavriya province - continental - with the black earths (chernozem) should be considered by the Katerynoslav station. For the first time, having introduced in 1907 the concept of "South Russian chernozem" instead of the existing "chocolate chernozem", he insisted that Crimea should be in coordination area of the Ekaterinoslav Oblast Station. Moreover, he proposed, additionally, taking into account the specificity of the Crimea, to create appropriate district institutions research fields and sites at the Katerynoslav Provincial Zemstvo Administration'smeeting on May 21-23, 1912. By the way, at a meeting in St. Petersburg on the organization of agricultural research business in 1908, the types of research institutions were also developed: 1) district regional research station, 2) in-district or local research station, 3) research fields and relevant institutions in other branches of rural farms, 4) research sites, 5) collective experiences.

Thus, as of the beginning of 1913, due to the relevant decision of the Tavriya Provincial Agricultural Council, it was proposed to expand the existing network of research sectoral institutions by creating: 1) a Central station, 2) 3 experimental fields and 3) a network of experimental sites. One of the stations was planned to be built on the Kerch Peninsula. The basic tasks or directions for the existing and established research institutions in the province are defined: "a) study of the province in agricultural and natural-historical relation for the development of more rational methods of arable farming and methods of weed and pest control, b) integration of activities of district research institutions ofprovince; c) the satisfaction of requests by the agronomic staff of the province. ${ }^{46}$ Research funding was proposed to successfully resolve the raised issues: 50\% from the Department of Agriculture, $25 \%$ from provincial zemstvo and $25 \%$ from county zemstvo.

${ }^{46}$ Klepynyn N. N. (1913) Proekto rhanyzatsyy opytnykhuch rezhdenyi v Tavryiskoi gubernii: (doklad Gubernskomu Selskokho ziaistvennomu Sovetu 6 dekabria 1912 goda) [The project of the organization of experimental institutions in the Tavrian province: (report to the Provincial Agricultural Council on December 6, 1912)]. Simferopol: Typ. Tavryisk. Hub. Zem-va. P. 11-12. (in Ukrainian). 
As time has shown, many of the Viner's V.V, Klepinin's M.M. and Rotmistrov's V.R. projects was finally implemented by the Soviet authorities, optimizing the administrative structure of Crimea. Thanks to $100 \%$ budget financing, in 1923 , it created not only a regional station, which was Klepinin's M.M. desire (now - the Institute of Agriculture of Crimea), but also the corresponding vertical of research and demonstration institutions of a certain specialization, which today is in search of optimal ways of adaptation in the conditions declared by the executive power of European integration and manifestations of globalization. For this, more than ever, the historical experience of the existence of a research before 1917, at least in matters of budgetary and organizational activity, may come in handy.

\section{SUMMARY}

The development of agricultural research in the Crimean Peninsula until 1920 was the result of the general evolution of its scientific and organizational approaches in the Russian Empire. It can be divided into four periods. The first - related to the creation of the NBG in 1812 and the search for forms of organization of research - its end came in 1897. Scientific research was largely unsystematic, dominated by the private initiative of large landowners to improve the productivity of crops and animals. Important role in the development of sectoral research during this period belonged to some prominent figures from France. The second period begins with the creation of the Oleshkovsky state vineyard nursery in 1897, which became the first state agricultural research institution for the needs of the region with an approved scientific program that envisaged adherence to appropriatemethods in conducting research in agronomy, ending in 1917.His general feature remained the dominance of the crop component of agronomic research, but with a specialization. The third period began in 1923 and ended on February 20, 2014 with a dividing into four conditional subperiods: 1923-1941, 1941-1944, 1944-1954, and 1954-2014. At the beginning of the first subperiod, "Crimean California" model, under the initiative of the American charity "Joint" led by Rosen I. and the relevant decision of the CEC of the RSFSR, was worked out. Characterized by the regional organization of agricultural research in the Crimean peninsula since 1923. It can be considered as a successful implementation of the Viner's V.V. project with Klepinin's addition. 
Since 1929, the regional form of sectoral research in the Crimea has become an integral part of the national coordinating system in the form of the All-Union Academy of Agricultural Sciences (AUAAS) through the institutionalized specialization of different areas of research.The only peculiarity was that a small number of Scientific Research Institutions functionedin the Crimean Peninsula, and sectoral research was directed exclusively to the needs of the RSFSR,as before the revolutionary events of 1917. During the Soviet-German War of 1941-1944, the Crimean Peninsula was merged in the General District of Crimea. All studies were conducted through the Agricultural and Forestry Research Center with headquarters in Kiev. In 1943 an independent service was created - the Regional Research Center in Kiev. It includes the sectoral research institutes, which are divided into three groups. A new revival of American preferential loansto Jewish immigrants to the Crimea, initiated by US President Roosevelt F., took place in 1944. Officially, the regional construction of agricultural research on the Crimean peninsula was introduced by the Resolution No. 259 of the Central Committee of the CPSU and the Council of Ministers of the USSR "On Measures to Improve the Work of Scientific Research Institutions(SRI) on Agriculture" of February 14, 1956. The methodological guidance of the whole cycle of Scientific Researches was performed by Ukrainian Academy of Agricultural Sciences(UAAS).Part of the experimental base of the Crimean peninsula was donated to the newly established sectoral Scientific Research Institutions, which have been involved in all the tasks of improving the productivity of fields and farms. After the decision of the Central Committee of the Communist Party of Ukraine and the RS SSR 487 of May 4, 1962 "On the elimination of UAAS and the formation of the department of agriculture in the Academy of Sciences of the USSR". The network of the agrarian profile of the Crimean Peninsula's SRIs became directly subordinated to the Ministry of Agriculture of Ukr.SSR or the Ministry of Agriculture of USSR. To accelerate the pace of agricultural development, on October 2, 1968, according to the Resolution of the Central Committee of the CPSU and the CM of the USSR "On measures for the further improvement of the Scientific Research in the field of agriculture" the Southern Branch (SB) of AUAAS was created. The changes in subordination occurred after the adoption of the CM of the USSR by Resolution No. 279 of 
September 22, 1990 "On the Establishment of the UAAS" in order to enhance the development of basic and applied research aimed at further improving the scientific support of agroindustrial complex. The Centers for Scientific support of the industrial productionwere created on the basis of regional state agricultural research stations and individual research institutes, among them the Autonomous Republic of Crimea. The attempt to change over agrarian science toan innovative component has led to the adoption of a new approach - the creation of regional educational research and production complexes. Institute of Agriculture of Crimea of NAASwasthe First among them. The fourthperiod of organizational construction of agricultural research in the Crimean peninsula is due, first of all, to the political component of the Russian Federation, namely its annexation. Local sectoral Scientific Research Institutionsare part of the coordination and budgetary funding system of the Russian Academy of Sciences. The research network, its functions and principles have remained virtually unchanged compared to functioning within the NAAS.

\section{REFERENCES}

1. Adamen A. F. (2009) Evoliutsyia landshaftov v Krymu (s peryoda antychnostypo nastoiashchee vremia) [The evolution of landscapes in the Crimea (from the period of antiquity to the present)]. Ahroekolohichnyi zhurnal, Cherv (spets. vyp.), pp. 27-31. (in Ukrainian).

2. Adamen F. F. (2011) Vnedrenye agronomycheskykh nauchnykh razrabotok $\mathrm{v}$ agropromyshlennom komplekse Ukrayny [Introduction of agronomic scientific developments in the agricultural sector of Ukraine]. Kyiv: Ahrar. nauka. (in Ukrainian).

3. Baltalona H. P. (1882) Imperatorskyi Nikitskyi sad v Krymu [Imperial Nikitsky Garden in Crimea]. Vestnyk sadovodstva, plodovodstva $i$ ogorodnichestva (orhanmImperatorskoho Rossyiskoho obshchestva sadovodstva). Oktiabr. pp. 528-537; noiabr. pp. 567-573; dekabr. pp. 628-634. (in Russian).

4. Verhunov V. A. (2009) Ahronomiia i stanovlennia nauky pro tvarynnytstvo na terenakh Ukrainy ta Frantsii (druha polovyna XVIII st. - 1920 rik) [Agronomy and the formation of animal science in the territory of Ukraine and France (second half of the eighteenth century - 1920)]. Kyiv. (in Ukrainian). 
5. Verhunov V. A. (2000) Vynyknennia doslidnoi spravy v zemlerobstvi Ukrainy: pivdenno-skhidnyi aspekt [The origin of a research case in Ukrainian agriculture: the southeastern aspect]. Aktualni problem istorii ahrarnoi nauky pivdnia Ukrainy (Ukraine. Kyiv. Cherven', 12, 2000). Kyiv. pp. 6-7. (in Ukrainian).

6. Verhunov V. A. (2012) Selskokhoziaistvennoe opytnoe delo na Krymskom poluostrove: nauchno-orhanyzatsyonnyi aspekt (k 200letyiu sozdanyia Nikitskogo botanycheskogo sada - Natsyonalnogo nauchnogo tsentra NAAN) [Agricultural experimental work on the Crimean peninsula: scientific and organizational aspect (on the 200th anniversary of the Nikitsky Botanical Garden - National Scientific Center of the NAAS)]: nauch. doklad. Kyev : FOP KORZUN D. Yu. (in Ukrainian).

7. Elyna O. Yu. (1995) Nauka dlia selskogo khoziaistva v Rossyiskoi imperii: formy patronazha [Science for agriculture in the Russian Empire: forms of patronage]. Sotsialnaya istoryia otechestvennoi nauki i tekhniki, no 1, pp. 40-63. (in Russian).

8. Elyna O. Yu. (2008) Ott sarskykh sadov do sovetskykh polei: istoryia selskokhoziaistvennykh opytnykh uchrezhdenyi XVIII 20-e gody XX v. [From Tsarist Gardens to Soviet Fields: the History of Agricultural Experimental Institutions of the XVIII - 20th years]: v 2 t. Moskva. T. 1., T. 2. (in Russian).

9. Zuev V. (1787) Puteshestvennye zapysky Vasylia Zueva ot S. Peterburga do Khersona v 1781 y 1782 godu [Travel notes of Vasil Zuev from St. Petersburg to Kherson in 1781 and 1782]. Sankt-Peterburh. (in Russian).

10. Klepynyn N. N. (1914) Krym, putevodytel [Crimea, guide]. Simferopol. (in Ukrainian).

11. Klepynyn N. N. (1913) Proekto rhanyzatsyy opytnykhuch rezhdenyi v Tavryiskoi gubernii: (doklad Gubernskomu Selskokho ziaistvennomu Sovetu 6 dekabria 1912 goda) [The project of the organization of experimental institutions in the Tavrian province: (report to the Provincial Agricultural Council on December 6, 1912)]. Simferopol: Typ. Tavryisk. Hub. Zem-va. (in Ukrainian).

12. Kochkyn M. A. (1967) Pochvy, lesa i klymat gornoho Kryma i puti ikh ratsionalnogo ispolzovanyia. Nauchnye trudy [Soils, forests and climate of the Crimea mountainous and ways of their rational use. Scientific works]. Moskva: Kolos. T. XVIII. (in Russian). 
13. Kriukova Y. (2011) Nikitskyi botanycheskyi sad. Istoryia i sud'by (k 200-letnemu yubyleiu) [Nikitsky Botanical Garden. History and fate (on the occasion of the 200th anniversary)]. Simferopol: N. Oryanda. (in Ukrainian).

14. Mytrofanov V. Y. (2007) [y dr.]. Mechta gertsoga de Ryshele - Nikitskyi botanycheskyi sad [Dream of the Duke de Richelieu - Nikitsky Botanical Garden]. Yalta: Dana Publishing, Poly PRESS. (in Ukrainian).

15. Kudashev V. A. (ed.) (1903) O neobkhodymosty luchshei orhanizatsyy opytnykh kultur, a ravno opytov po akklymatyzatsi i novykh i maloyzvestnykh rastenyi v razlychnykh mestnostiakh Rossii. Doklad 2-mu siezdu A. S. Ermolova [On the need for better organization of experimental crops, as well as experiments on the acclimatization of new and little-known plants in various places of Russia. Report of A. S. Ermolovto the 2nd Congress]. Zemledelcheskaia hazeta, no 5, pp. 155. (in Russian).

16. Petrov Y. P., Vereshchahyn N. V. (ed.) (1893) O puteshestvii po Rossii Ministra Zemledelyia [About the trip to Russia of the Minister of Agriculture]. Vestnik russkogo selskogo khoziaistva, no 36, p. 609. (in Russian).

17. Typohraf. V. F. Kyrshbauma. (1904) Obzor deiatelnosti Ministerstva zemledelyia i gosudarstvennykh imushchestv za desiatyi god ego sushchestvovanyia [Overview of the activities of the Ministry of Agriculture and State Property for the tenth year of its existence]. Sankt-Peterburh. (in Russian).

18. Palympsestov Y. (1868) Obozrenie razlichnykh otraslei selskogo khoziaistva [Overview of various agricultural sectors]. Sbornik statei o selskom khoziaistve Yuga Rossiii zvlechennykhiz Zapisok Imperatorskogo obshchestva selskogo khoziaistvayuzhnoi Rossii s 1830 po 1868 god. Odessa: Typ. P. Frantsova. (in Russian).

19. Potekhyn V. E. (1976) Nikitskyi botanicheskyi sad v razvitii selskogo khoziaistvayuga Rossii (1812-1861 gg.) [Nikitsky Botanical Garden in the Development of Agriculture in the South of Russia (1812-1861)]: avtoref. dys. na soyskanye nauch. step. kand. yst. nauk. Moskva. (in Russian).

20. Rotmystrov V. H. (1898) Proekt orhanizatsii opytnykh polei v Rossii [The project for the organization of experimental fields in Russia]. Odessa: Ekonomycheskaia typohraf. ilytohraf. (in Ukrainian). 
21. Radchenko V. A. (2007) Ydentychnost y razvytye tendentsyi otechestvennoho y zarubezhnoho opttnychestva [Identity and development of trends in domestic and foreign experience]. Symferopol : OAL Symferopolskaia gorodskaia typohrafyia (SHT). (in Ukrainian).

22. Romanovskyi-Romanko A. S. (1910) Vynohradnyky y maslychnыe pytomnyky Departamenta zemledelyia [Vineyards and oil nurseries of the Department of Agriculture. 1909]. Ezhehodnyk Hlavnoho upravlenyia zemleustroistva y zemledelyia po Departamentu zemledelyia (hod tretyi). Sankt-Peterburg : Typ. V. F. Kyrshbauma. (in Russian).

23. Typo-lytohr. M. P. Frolovoi. (1911) Sbornyk svedenyi o selskokhoziaistvennykh opytnykh uchrezhdenyiakh Rossyy (po dannym ankety 1910 hoda) [Collection of information on agricultural experimental institutions of Russia (according to the data of 1910)]. Sankt-Peterburg. (in Russian).

24. Typo-lytohr. M. P. Frolovoi. (1913) Sbornyk svedenyi o selskokhoziaistvennykh opytnykh uchrezhdenyiakh Rossyy (po dannym ankety 1912 hoda) [Collection of information on agricultural experimental institutions of Russia (according to the data of the 1912)]. Sankt-Peterburg. Vol. 2. (in Russian).

25. Sekurov N. K.(1998) Tri vstrechi s Khrystyanom Stivenom [Three meetings with Christian Steven]. Symferopol. (in Ukrainian).

26. Nauka. (1974) Stiven Khrystyan Khrystyanovych [Steven Christian Hristianovich]. Akademyia nauk SSSR. Personalnyi sostav. Kn. 1 (1724-1917). Moskva. (in Russian).

27. Shcherbakov M. F. (1911) Imperatorskyi Nikitskyi sad. 1910 [Imperial Nikitsky Garden. 1910]. Ezhehodnyk Hlavnoho Upravlenyia Zemleustroistva y Zemledelyia po Departamentu zemledelyia (hod chetvertbii). Peterburg, pp. 630-645. (in Russian).

\section{Information about the author: Viktor Vergunov,} Doctor of Agricultural Sciences, Professor,

Academician of NAAS, Director, National Scientific Agricultural Library of NAAS 10, Heroiv Oborony St., Kyiv, Ukraine ORCID ID: orcid.org/0000-0002-5476-4845 